\title{
PENGEMBANGAN DAN PENGELOLAAN DESA WISATA PASAR PANCINGAN DI DESA BILABANTE KECAMATAN PRINGGARATA LOMBOK TENGAH
}

\author{
Ahmad Syukron Sidik ${ }^{1}$, Farizan Fahmi ${ }^{2}$ \\ ${ }^{1}$ Universitas Qamarul Huda Badaruddin. Email: syukron47@gmail.com \\ 2 Universitas Qamarul Huda Badaruddin. Email: farizan@uniqhba.ac.id
}

\begin{abstract}
Tourism is a new source of economic growth in NTB. Data from the NTB tourism office noted that the progress of the tourism sector in NTB province was marked by the increasing number of foreign and domestic tourist arrivals each year. In 2016 the number of tourists visiting NTB was 3.1 million, in 2017 the realization reached 3.8 million. This means exceeding the 2017 target of 3.5 million. While in 2018 it is targeted to be able to attract up to 4 million tourists. The fishing market has its own attraction in developing the potential of its human and natural resources. Based on the results of the preliminary study, specifically identified the main problems faced by the partner group partners, among others, the field of management and management of tourist villages, the lack of skills in processing typical snacks, marketing systems that are still conventional. The method used in this community service activity is to use a CBT-based community participation approach that promotes lecture, discussion, practice, and demonstration methods as well as the presentation of results. This service program is able to provide skills to partners in solving the problems they face.
\end{abstract}

Keywords: Village tourism, community participation

\begin{abstract}
ABSTRAK
Pariwisata adalah sumber pertumbuhan ekonomi baru di NTB. Data dinas pariwisata NTB mencatat, kemajuan sektor pariwisata di Provinsi NTB ditandai dengan meningkatnya angka kunjungan wisatawan mancanegara dan nusantara setiap tahun. Pada tahun 2016 jumlah wisatawan yang berkunjung ke NTB sebanyak 3,1 Juta, tahun 2017 realisasinya mencapai 3,8 juta. Ini berarti melebihi target tahun 2017 sebanyak 3,5 juta. Sementara tahun 2018 ditargetkan bisa menarik kunjungan hingga 4 juta wisatawan. Pasar pancingan memiliki daya tarik tersendiri dalam mengembangan potensi sumber daya manusia dan alam yang dimiliki. Berdasarkan hasil studi pendahuluan, secara spesifik teridentifikasi permasalahan utama yang dihadapi oleh mitra kelompok mitra antara lain, bidang manajemen dan pengelolaan desa wisata, kuranganya keterampilan dalam mengolah jajanan khas, system pemasaran yang masih konvensional. Metode yang digunakan dalam kegiatan pengabdian ini adalah dengan menggunakan pendekatan partisipasi masyarakat berbasis CBT (community based tourism) yang mengedepankan metode ceramah, diskusi, praktikum, dan demonstrasi serta presentasi hasil. Program pengabdian ini mampu memberikan keterampilan kepada mitra dalam menyelesaikan masalah yang mereka hadapi.
\end{abstract}

Kata Kunci: Desa wisata , partisipasi masyarakat

\section{PENDAHULUAN}

Pemerintah Provinsi Nusa Tenggara Barat melalui Dinas Pariwisata NTB sedang fokus mengembangkan desa wisata. Berdasarkan data dinas pariwisata, NTB memiliki potensi besar dalam pengembangan desa wisata. keragaman potensi wisata desa yang bisa menjadi alternatif pilihan bagi para wisatawan kala berkunjung ke lombok. Hal ini juga linier dengan kebijakan pemerintah pusat dalam menumbuhkan semangat 
kepariwisataan juga harus membangun desa. Desa wisata merupakan salah satu bentuk penerapan pembangunan pariwisata berbasis masyarakat dan berkelanjutan. Melalui pengembangan desa wisata diharapkan terjadi pemerataan yang sesuai dengan konsep pembangunan pariwisata yang berkesinambungan. Di samping itu, keberadaan desa wisata menjadikan produk wisata lebih bernilai budaya pedesaan sehingga pengembangan desa wisata bernilai budaya tanpa merusaknya.

Pariwisata adalah sumber pertumbuhan ekonomi baru di NTB. Data dinas pariwisata NTB mencatat, kemajuan sektor pariwisata di Provinsi NTB ditandai dengan meningkatnya angka kunjungan wisatawan mancanegara dan nusantara setiap tahun. Jika tahun 2016 jumlah wisatawan yang berkunjung ke NTB sebanyak 3,1 Juta, tahun 2017 realisasinya mencapai 3,8 juta. Ini berarti melebihi target tahun 2017 sebanyak 3,5 juta. Sementara tahun 2018 ditargetkan bisa menarik kunjungan hingga 4 juta wisatawan. Target ini optimis tercapai. Di sisi lain pertumbuhan investasi bidang kepariwisataan di Provinsi tetangga Bali ini juga meningkat sebesar 22 persen sepanjang tahun 2017, juga meningkat bila dibanding tahun 2016 yang pertumbuhannya sekitar 19 persen. Kepala Dinas Pariwisata NTB Lalu Mohammad Faozal menilai pertumbuhan investasi kepariwisataan di NTB tahun 2017 mencapai 22 persen. Sektor pariwisata ini menjadi penyumbang tertinggi investasi di wilayah NTB tahun 2017. Isu utama dalam pengembangan desa wisata adalah mengenai kontribusi positif aktifitas pariwisata di desa wisata terhadap kehidupan ekonomi masyarakat lokal (Hariyanto, 2016).

Berdasarkan hasil studi pendahuluan, secara spesifik teridentifikasi permasalahan utama yang dihadapi oleh mitra kelompok mitra, yaitu:

1) Pengelola Desa Wisata Pasar Pancingan belum memiliki keterampilan rancangan dalam mengelola dan mengembangakan desa wisata.

2) Desa Wisata Pasar Pancingan belum memiliki keahlian atau keterampilan dalam membuat/mengolah aneka macam produk unggulan (jajanan khas) dari hasil petani atau masyarakat setempat.

3) Pengelolan Desa Wisata Pasar Pancingan tidak pernah menampilkan atraksi menarik demi meningkatkan jumlah kunjunan.

4) Minimnya keterampilan dalam melakukan pemasaran desa wisata.

5) Desa Wisata Pasar Pancingan belum memiliki keterampilan melakukan inovasi baru dalam mengelola desa wisata dari yang skala desa menjadi nasional.

6) Mitra sasaran belum memiliki keterampilan melakukan perubahan manajemen desa wisata dari manajemen tradisional, manajemen kekeluargaan ke manajemen yang bersifat umum atau publik; dan

7) Pengelola Desa Wisata Pasar Pancingan belum membuat langkah preventif dalam melindungi (kearifan desa wisata dari ancaman budaya luar).

Pengembangan sumber daya manusia dalam mengelola, mengembangkan dan memasarkan desa wisata menjadi fokus utama penelitian ini. Hal ini dinilai menjadi faktor penting untuk memajukan desa wisata sehingga masyarakat bisa menikmati secara langsung mamfaat adanya wisata desa di daerahnya. Pengembangan desa wisata adalah salah satu program yang harus dapat perhatian dari pemerintah melalui Kementerian Desa Pembangunan Daerah Tertinggal dan Transmigrasi sekaligus 
Kementerian Pariwisata. Desa wisata terbukti mampu menciptakan lompatan ekonomi sekaligus sosial bagi warga desa wisata sekaligus membuat pariwisata Indonesia semakin kuat di mata dunia. Keberhasilan pengembangan desa wisata tergantung pada tingkat penerimaan dan dukungan masyarakat lokal (Wearing, 2001). Menurut I. Pitana (2009), pembangunan dan pengembangan pariwisata secara langsung akan menyentuh dan melibatkan masyarakat, sehingga membawa berbagai dampak terhadap masyarakat setempat, bisa dampak positif maupun negatif. Bagi masyarakat, pengembangan pariwisata memiliki potensi manfaat yang sangat besar bagi ekonomi, sosial-budaya dan lingkungan namun terkadang sering terjadi pengembangan pariwisata yang salah justru membawa banyak kerugian bagi masyarakat lokal itu sendiri.

\section{METODE PELAKSANAAN}

Metode yang digunakan dalam kegiatan pengabdian ini adalah dengan menggunakan pendekatan partisipasi masyarakat berbasis CBT (community based tourism) yang mengedepankan metode ceramah, diskusi, praktek, dan demonstrasi serta presentasi hasil. Materi yang telah diberikan oleh pembicara ke pada mitra selajutnya diadakan diskusi dan tanya jawab. Kegiatan ini dilakukan supaya peserta pelatihan memahami materi yang disampaikan seperti materi tentang pengelolaan desa wisata, pemasaran desa wisata, pengolahan jajanan khas dan spa kebugaran. Selanjutnya, pemateri membagi peserta menjadi beberapa kelompok untuk memudahkan memantau perkembangan peserta pelatihan. materi yang telah dikuasi akan dilakukan praktik, seperti praktik pengolahan jajan dan membuat spot photo baru.

Kegiatan mempresentasikan hasil praktik merupakan kegiatan akhir dalam metode CBT ini. Pola ini digunakan dengan harapan dapat meningkatkan kompetensi pengelola desa wisata dalam menyelesaikan masalah yang dihadpi oleh mitra. Memberikan pelatihan-pelatihan bagi seluruh komponen desa, termasuk pemerintah desa tentang manajemen pariwisata, bagaimana mengelola tempat wisata, manajemen tamu/pengunjung, beserta inovasi-inovasi yang perlu dikembangkan mengingat sebagaimana sektor lainnya sektor pariwisata pun mengalami fluktuasi dan bisa mengalami "kejenuhan" . Berkaitan dengan masih konvensionalnya cara-cara promosi yang dilakukan selama ini seperti penerbitan bahan cetak baik booklet maupun leaflet, promosi tatap muka baik dengan model pameran maupun travel dialogue, serta promosi melalui media massa, ada baiknya mengikuti kemajuan jaman dengan membuka Situs Pariwisata di dunia maya/internet tanpa mengesampingkan cara-cara sebelumnya.

Untuk mencapai target luaran, maka hal-hal mendasar yang dilakukan adalah sebagai berikut: sosialisasi kepada masyarakat yang dilakukan yaitu dengan melibatkan pengelola, pemerintah desa dan masyarakat setempat dengan metode musyawarah dan tanya jawab untuk menentukan jumlah peserta pelatihan, menentukan waktu dan tempat pelatihan, penyusunan materi pelatihan, praktikum dan presentasi hasil dari setiap kegiatan yang dilakukan.

\section{HASIL DAN PEMBAHASAN}


Berdasarkan hasil pengamatan yang dilakukan tim PKM pada saat kegiatan berlangsung, antusian peserta pelatihan sangat tinggi, baik dari materi yang diberikan, diskusi,praktikum dan presentasi hasil. Hal ini ditunjukkan dengan aktifnya peserta dalam bertanya pada narasumber. Keaftifan narasumber dan peserta membuat suasana pelatihan dengan metode CBT menjadi proaktif. Peserta memiliki rasa ingin tahu dalam meningkatkan pengetahuan dan keterampilam dalam memajukan desa wisata yang mereka kelola. Pelaksanaan kegiatan pengabdian ini berlangsung selama tiga bulan, yaitu dari bulan Mei sampai Agustus 2019. Kegiatan yang dilakukan selama tiga bulan tersebut meliputi, penyampaian materi, diskusi dengan narasumber, praktikum dan presentasi hasil. Kegiatan pelatihan ini bertempat di Aula kantor desa Bilabante, secretariat pasar pancingan serta lokasi desa wisata Bilabante. Pelaksanaan dalam setiap kegiatan pelatihan berlangsung selama 6 jam 30 menit.

\section{Tahap persiapan}

Pada tahap ini, langkah pertama yang dilakukan tim pengabdian yaitu melakukan sosialisa kepada mitra. Hal ini dilakukan guna menentukan jadwal pelatihan mempersiapkan sarana dan prasarana pelatihan serta mempersiapkan materi yang akan disampaikan oleh narasumber.

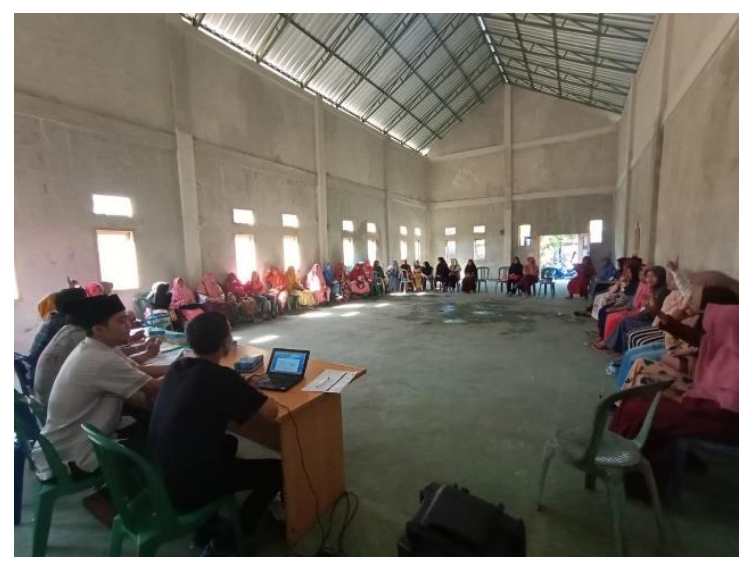

Gambar 1. Sosialisasi dengan Mitra

\section{Tahap Pelaksanaan}

Pada pelaksanaan kegiatan pengabdian yang dilakukan selama empat bulan, sejak bulan Mei sampai Agustus 2019, narasumber memberikan beberapa materi antara lain, pengelolaan desa wisata, managemen pemasaran desa wisata, pengolahan jajanan khas dan spa kebugaran. Pelaksanaan kegiatan ini menggunakan metode Community Based Tourim (CBT). Materi yang diberikan oleh narasumber yang diikuti dengan tanya jawab dan diskusi menjadi kegiatan pelatihan ini lebih efektif. Praktikum yang dilakukan memberikan manfaat bagi peserta yaitu dapat memberikan pengalaman khususnya dalam memajukan desa wisata dan menambah pengetahuan peserta terhadap materi yang diberikan oleh narasumber. Kegiatan terakhir pada tahap pelaksanaan yaitu presentasi dari hasil praktikum. Presentasi ini memotivasi peserta dalam 
mengembangan diri, berani berinovasi dan mampu memberikan contoh kepada peserta yang lain.

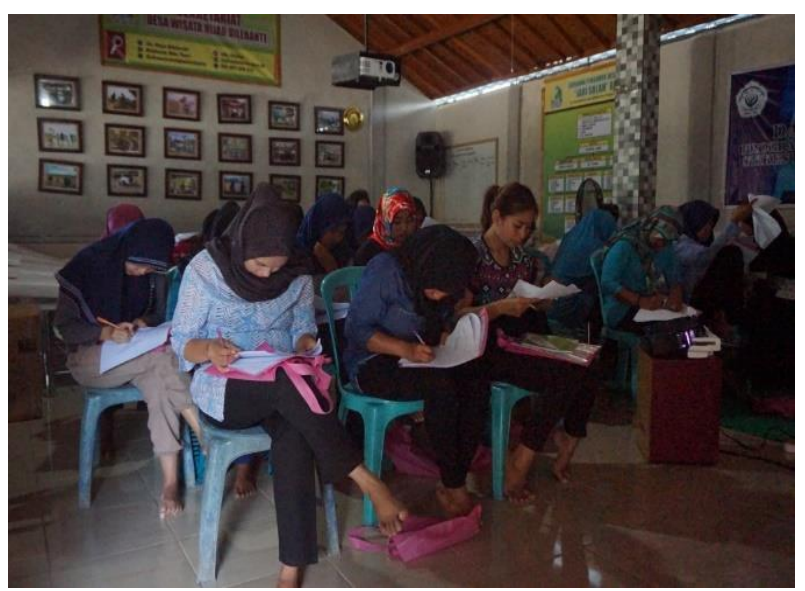

Gambar 2. Kegiatan Pelatihan

Musyawarah dan tanya jawab pada Kegiatan awal pengabdian ini menunjukkan $30 \%$ pengelola dan masyarakat setempat memahami tentang konsep, managemen dan pengelolaan desa wisata. Setelah melakukan kegiatan penyuluhan, diskusi praktikum dan presentasi, $85 \%$ pengelola dan masyarakat memiliki pengetahuan dan keterampilan dalam mengembangkan desa wisata Pasar Pancingan. Tuntutan pengetahuan dan keterampilan dalam pengelolaan desa wisata berbasis masyarakat sesuai dengan kebutuhan dunia pariwisata saat ini. Kesadaran masyarakat dalam berpartisipasi secara langsung terhadap perkembangan desa menjadikan mesyarakat mandiri secara ekonomi, serta mampu mengelola dan mengembangkan desa wisata. Program kemitraan masyarakat ini meliputi pelatihan menagemen desa wisata, pemasaran desa wisata, pengolahan jajanan dan wisata kebugaran.
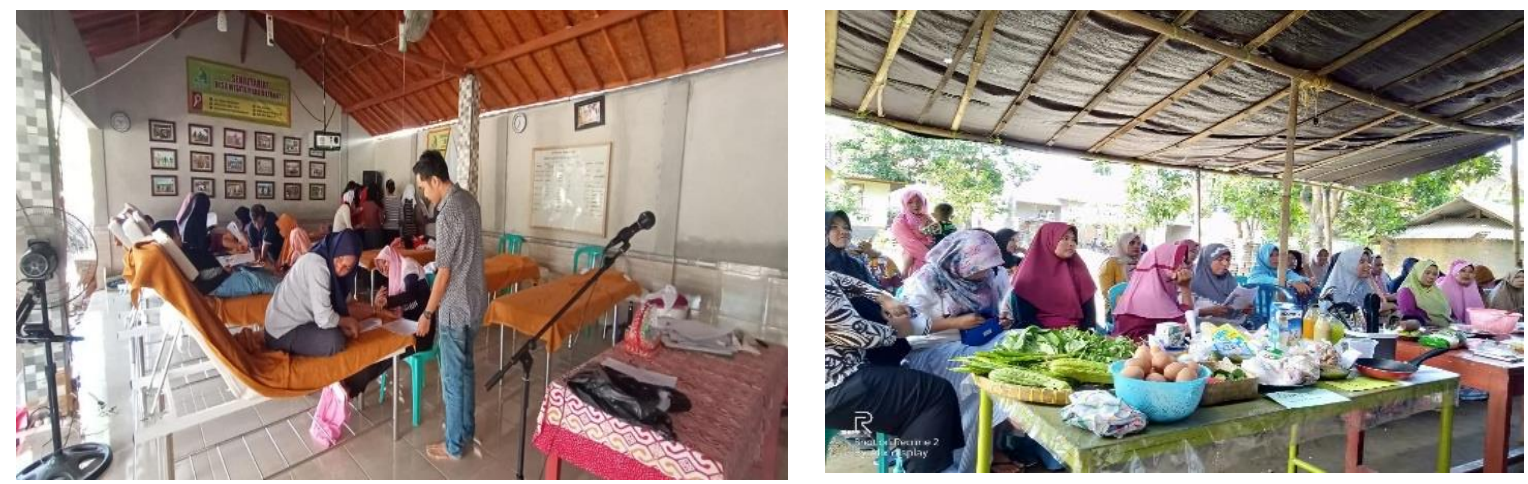

Gambar 3. Kegiatan Praktikum

Masyarakat memiliki prilaku sadar wisata yang meliputi kebersihan, kerapian, kesopanan, keamanan dan kenangan. Keterampilan dalam mengolah jajanan meningkatkan hasil penjualan yang berdampak pada tingkat perekonomian masyarakat. Masyarakat memiliki prilaku sadar wisata yang mampu membangun lokasi wisata di daerah itu, memperlakukan tamu dengan baik, membangun rasa nyaman bagi pengunjung, membuat lokasi wisata yang bersih, aman, nyaman dan menyenangkan. 
Terbentuknya spa terapi kebugaran kesehatan berupa pijak kaki, badan dan wajah yang merupakan hal baru bagi desa wisata pasar pancingan. Pengelola dapat menjalin kemitraan dengan pemerintah dan organisasi atau usaha yang berkaitan dengan pariwisata seperti, GENPI Lombok Sumbawa,travel agent, pemandu wisata seta instansi terkait. Program pengabdian ini dapat langsung dirasakan masyarkat karena pendekatan yang digunakan adalah Community Based Tourism yang melibatkan partisipasi masyarakat.

\section{SIMPULAN}

Pelatihan dan praktikum yang telah dilakukan memberikan masyarakat keterampilan dalam mengembangkan dan mengelola desa wisata pasar pancingan. Program pengabdian ini memotivasi masyrakat terhadap perkembangan desa wisata yang mereka miliki. Berbagai pelatihan yang dilakukan memotivasi masyarakat untuk terus berinovasi dalam mengembangan desa wisata. Selain itu, Program pengabdian ini menjadikan masyarakat dan pengelola memiliki kemampuan dalam managemen desa wisata, pemasaran desa wisata, olahan jajanan khas, serta spa kebugaran.

\section{UCAPAN TERIMA KASIH}

Tim pengabdian masyarakat ini mengucapan terima kasih kepada ristekdikti yang telah mendanai program hibah, masyarakat Desa Bilabante telah mengikuti program ini, Universitas Qamarul Huda Badaruddin telah memberikan dukungan.

\section{DAFTAR RUJUKAN}

Adiyoso, W. (2009). Menggugat Perencanaan Partisipatif dalam Pemberdayaan Masyarakat. Jakarta: ITS Press.

Hariyanto, O. I. B. (2016). Destinasi Wisata Budaya Dan Religi Di Cirebon. Ecodemica, $4(2), 214-222$.

Pitana, I. G., dan Gayatri, P. G. (2005). Sosiologi pariwisata. Yogyakarta: Penerbit Andi.

Timothy, D. J. (1999). Participatory Planning a View of Tourism in Indonesia. Annals of Research, 26(2).

Wearing, S. L. and Donald, Mc. (2001). "The Development of Community Based Tourism: Re-Thinking The Relationsgip between Tour Operators and Development Agents as intermediaries in rural and isolated area Communities. Journal of sustainable tourism. 